\title{
Avaliação da camada de óxidos formada a altas temperaturas em aços inoxidáveis utilizados como interconectores para PaCOS
}

\author{
Evaluation of oxide layer formed at high temperatures \\ in stainless steel used as SOFC interconnects
}

Oliveira, B. F., Terra, D.G.S., Terrones, L.A.H.

\begin{abstract}
Laboratório de Materiais Avançados - LAMAV, Centro de Ciência e Tecnologia, Universidade Estadual do Norte Fluminense Darcy Ribeiro, CCT/UENF, av. Alberto Lamego, 2000, 28015-620, Campos dos Goytacazes, RJ - Brasil. e-mail: barbara.fo@gmail.com ; debbyterra@yahoo.com.br ; lucho@uenf.br
\end{abstract}

\section{RESUMO}

No presente trabalho avalia-se o comportamento de um aço inoxidável ferrítico AISI 430 em altas temperaturas visando o seu uso como interconector em pilhas a combustível de óxido sólido (PaCOS), evidenciando principalmente a morfologia, a composição química da camada de óxido formada e a variação microestrutural manifestada principalmente na variação do tamanho do grão. Amostras deste aço foram tratadas isotermicamente a $650^{\circ} \mathrm{C}, 850^{\circ} \mathrm{C}$ e $1050^{\circ} \mathrm{C}$ em diferentes tempos. Esta análise foi realizada com uso das técnicas de microscopia eletrônica de varredura e difração de raios-X. Os resultados indicam que a $650^{\circ} \mathrm{C}$ já foram observadas evidências da formação de uma camada muito fina de óxidos. Nas temperaturas de $850^{\circ} \mathrm{C}$ e $1050^{\circ} \mathrm{C}$ observou-se o crescimento dos grãos e formação de uma camada de óxidos constituída por pequenos “microcristais” contendo $\mathrm{O}, \mathrm{Fe}, \mathrm{Cr}$ e $\mathrm{Mn}$ na sua composição.

Palavras chaves: Aço inoxidável ferrítico, oxidação, interconectores, PaCOS.

\begin{abstract}
In this work the behaviour of type AISI 430 ferritic stainless steel at high temperatures and its use as SOFCs interconnect material is evaluated. The main objective is to show the morphologic chemistry composition of the oxide layer formed in such circumstances as well as the microstructural variation revealed by its grain size. The Samples of this type of steel were heat treated isothermally at $650^{\circ} \mathrm{C}, 850^{\circ} \mathrm{C}$ and $1050^{\circ} \mathrm{C}$ at several holding times. They were characterized by scanning electron microscopy and X-ray diffraction. The results indicate that at $650^{\circ} \mathrm{C}$ evidence of a very thin oxide layer formation was already found. Furthermore, at the temperatures of $850^{\circ} \mathrm{C}$ and $1050^{\circ} \mathrm{C}$ it grain growth and formation of an oxide layer consisting of small microcrystals with $\mathrm{O}, \mathrm{Fe}, \mathrm{Cr}$ and $\mathrm{Mn}$ in their composition were observed.
\end{abstract}

Keywords: Stainless steel, oxidation, interconnect, SOFC.

\section{INTRODUÇÃO}

As pilhas a combustível de óxido sólido (PaCOS) são dispositivos que apresentam alta eficiência energética, pois elas convertem diretamente energia química em energia elétrica através da reação de oxidação eletroquímica entre um combustível e um oxidante. Além disso, elas emitem menos poluentes agredindo menos o meio ambiente [1,2].

Estruturalmente toda pilha é composta de uma sequência de unidades, cada uma com quatro componentes: o eletrólito, anodo, catodo e o interconector, sendo estes conjuntos vedados por um material selante. Todos os componentes devem apresentar uma boa estabilidade química e bom ajuste do coeficiente de expansão térmica $[3,4]$.

Usualmente as PaCOS operam em altas temperaturas. No intervalo entre $800-1000^{\circ} \mathrm{C}$, devido à degradação física e química, os materiais utilizados como interconectores são cerâmicos. Em temperaturas 
consideradas intermediárias $\left(600-800^{\circ} \mathrm{C}\right)$, os aços inoxidáveis ferríticos tornam-se uma boa alternativa devido ao fato de eles possuírem coeficiente de expansão térmica próxima ao dos materiais cerâmicos e serem mais vantajosos em alguns aspectos em relação ao material cerâmico, dentre eles: o baixo custo, a impermeabilidade gasosa, a usinabilidade e alta resistência mecânica. A desvantagem para o uso do aço inoxidável como interconector é a exposição simultânea de uma face para o ar e outra para o combustível, além da evaporação do cromo. Para resolver o problema no lado exposto ao combustível, normalmente o aço é recoberto com um filme, por exemplo, de cromita de lantânio [5, 6, 7].

O comportamento em serviço dos aços inoxidáveis a altas temperaturas envolve a formação de uma camada de óxido na superfície e uma variação microestrutural relacionado ao tamanho de grão. Neste trabalho, foi avaliado o comportamento de um aço ferrítico 430 durante tratamentos isotérmicos a $650^{\circ} \mathrm{C}$, $850^{\circ} \mathrm{C}, 1050^{\circ} \mathrm{C}$ analisando a camada de óxido e variação microestrutural que poderiam influenciar durante a deposição do filme ou na operação da pilha.

\section{MATERIAIS E MÉTODOS}

O material utilizado foi um aço inoxidável ferrítico AISI-430, o qual foi recebido na forma de chapa fina de $1 \mathrm{~mm}$ de espessura, com a composição química nominal dada na Tabela 1:

Tabela 1: Composição química nominal (\% em peso) do aço inoxidável ferrítico AISI-430.

\begin{tabular}{l|l|l|l|l|l|l}
\hline AÇO & C (\%) & MN (\%) & SI (\%) & CR (\%) & NB (\%) & N (PPM) \\
\hline AISI 430 & 0,02 & 0,18 & 0,30 & $16,00-18,00$ & 0,40 & 220 \\
\hline
\end{tabular}

Desta chapa foram retiradas amostras de 1x2cm através de cortes feitos com discos abrasivos de alumina. Essas amostras foram preparadas de acordo com os procedimentos da preparação metalográfica: lixamento, polimento mecânico com alumina. Foi realizado o ataque eletrolítico nas amostras em que se encontrou necessidade. A norma seguida para este foi a ASTM A-262, que consiste em dissolver $10 \mathrm{~g}$ de ácido oxálico $\left(\mathrm{H}_{2} \mathrm{C}_{2} \mathrm{O}_{4} \cdot 2 \mathrm{H}_{2} \mathrm{O}\right)$ em $100 \mathrm{ml}$ de água destilada. Durante o ataque foi utilizada uma corrente de $0,18 \mathrm{~A}$ e uma voltagem de $2,0 \mathrm{~V}$ durante 60 segundos.

Os tratamentos isotérmicos foram realizados ao ar num forno elétrico tipo mufla nas temperaturas de $650^{\circ} \mathrm{C}$ por 3 horas, $850^{\circ} \mathrm{C}$ por 3 e 12 horas e a $1050^{\circ} \mathrm{C}$ por 3 e 10 horas. A análise microestrutural do material, morfologia e composição da camada de óxidos foi realizada no MEV SHIMADSU MODELO SSX-550M e a análise de raios-X, no difratômetro SHIMADZU MODELO 7000.

\section{RESULTADOS E DISCUSSÃO}

\subsection{Materiais como recebido}

O aspecto geral da microestrutura do aço inoxidável ferrítico 430 na condição como recebido é apresentado na Figura 1. Nesta micrografia pode-se observar que os grãos são equiaxiais e possuem característica de um material laminado a quente acima da temperatura de recristalização. Este aço é monofásico constituído apenas por grãos da fase ferrítica com um tamanho médio de 15,5 $\mu \mathrm{m}$. Esta microestrutura observada para o aço inoxidável em estudo, ferrítico 430, é típico desta família de aços [8, $\underline{9} \underline{10]}$.

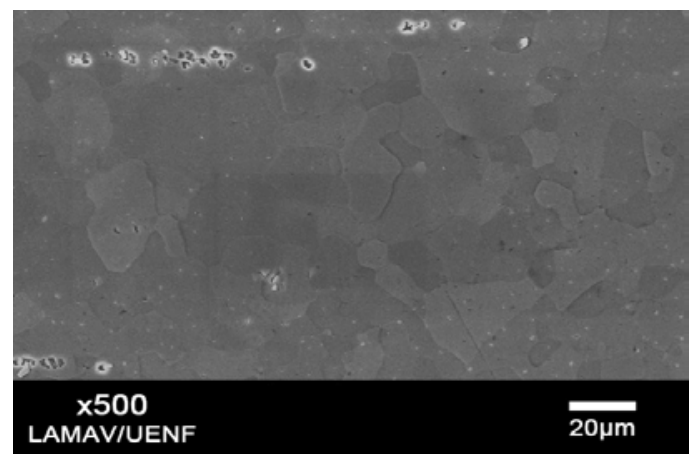

Figura 1: Micrografia do material como recebido indicando material monofásico com grãos de ferrita. 
Para uma melhor caracterização micro e subestrutural do material foram obtidas micrografias e realizadas microanálises EDS no plano superior e paralelo à direção de laminação.

Na Figura 2b, apresenta-se o espectro EDS do ponto 1 na matriz ferrítica, indicando a presença de Fe e Cr, principalmente. No espectro EDS do ponto 2 apresentado na Figura 2c destaca-se, além da presença de Fe e Cr, um pico intenso de $\mathrm{Nb}$, o que confirma a presença de carbeto de $\mathrm{Nb}$. Estas partículas estabilizadoras de carbeto de $\mathrm{Nb}$, que são formadas durante a solidificação, permanecem sempre no material. A importância destes precipitados a base de carbeto de $\mathrm{Nb}$ é que estes inibem a sensitização do aço. A identificação e a distribuição deste elemento foram estudadas por outros autores [7].

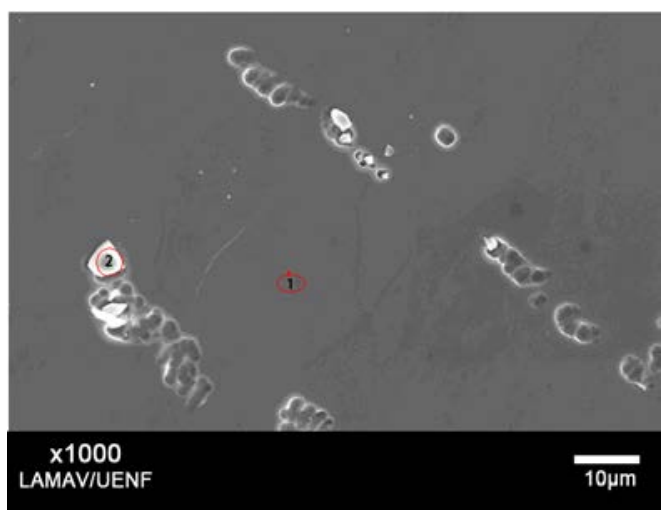

(a)

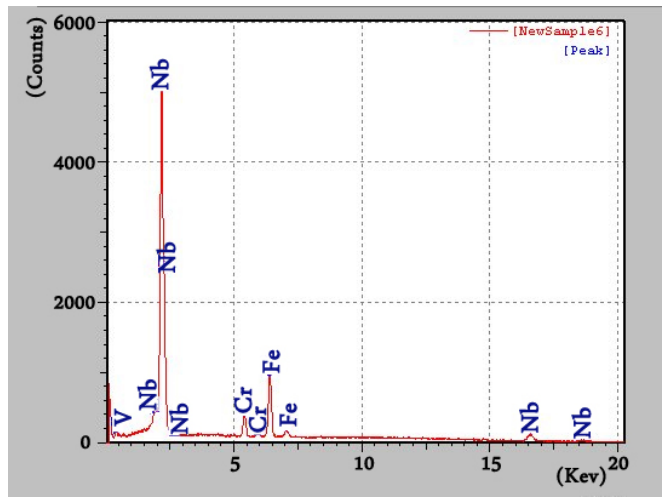

(c)

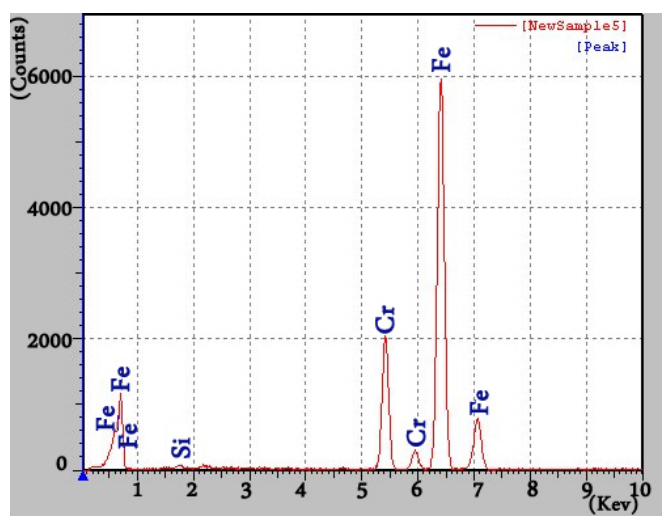

(b)

Figura 2: (a) Micrografia do material como recebido; (b) microanálise EDS do ponto 1, matriz; (c) microanálise EDS do ponto (2), partículas estabilizadoras de carbeto de $\mathrm{Nb}$.

\subsection{Material tratado a $650^{\circ} \mathrm{C}$}

No material que foi submetido à temperatura de $650^{\circ} \mathrm{C}$ durante 3 horas, já foi possível observar evidências da presença de uma camada muito fina de óxidos (Figura 3). Ela ofuscou a superfície, mas não precisou ser removida para a observação da microestrutura.

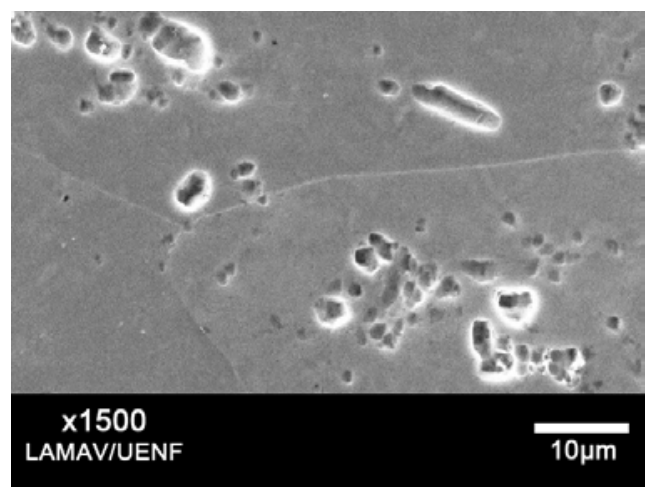

Figura 3: Microestrutura do material tratado a $650^{\circ} \mathrm{C}$ por 3 horas. 


\subsection{Material tratado a $850^{\circ} \mathrm{C}$}

Quando o material foi tratado a $850^{\circ} \mathrm{C}$ durante 3 horas, a morfologia da camada de óxidos apresentou-se uniforme e contínua como mostrado na Figura 4a. As pequenas partículas ou microcristais que constituem esta camada têm uma morfologia geométrica poliédrica (Figura 4b). A microanálise química EDS desses cristais é mostrada na Figura 4.c. Ela foi realizada de maneira pontual e indicou a presença dos elementos Cr, Fe, O.

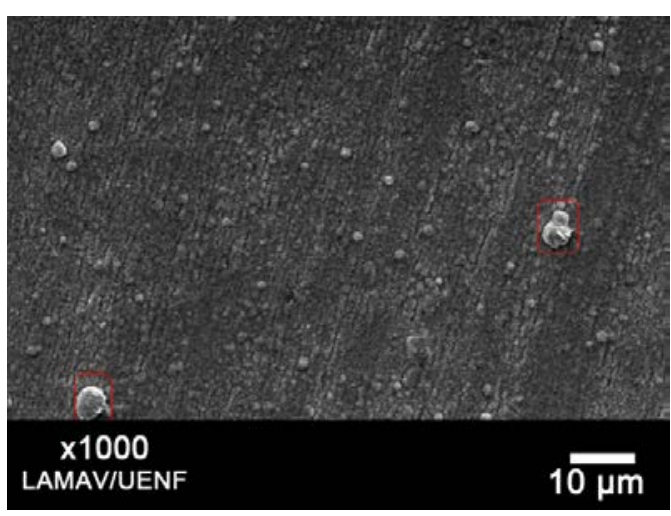

(a)

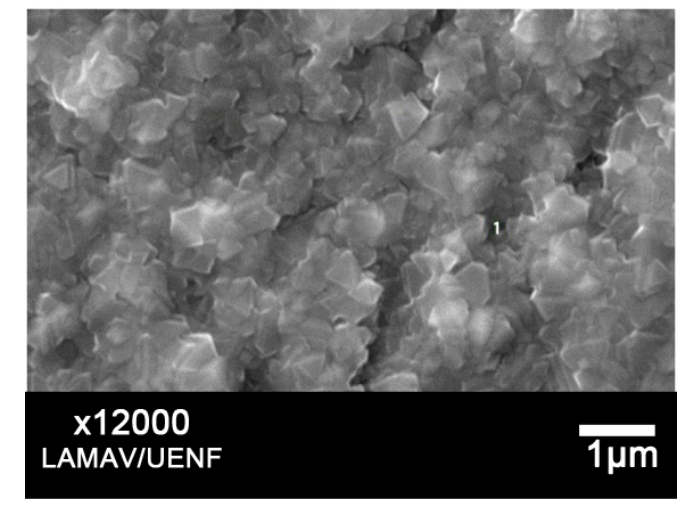

(b)

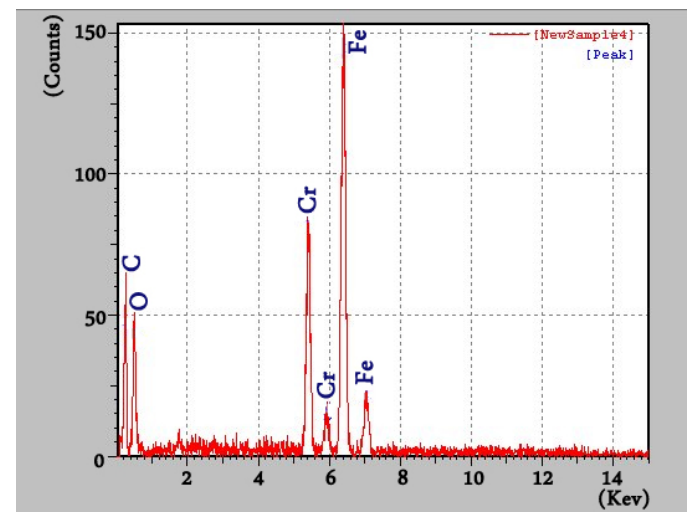

(c)

Figura 4: (a) Morfologia da camada oxidada no material tratado a $850^{\circ} \mathrm{C}$ por 3 horas; (b) microcristais que constituem a camada oxidada que possuem morfologia geométrica; (c) microanálise EDS do ponto 1 da micrografia (b).

No caso do material tratado a $850^{\circ} \mathrm{C}$ por 12 horas, a camada oxidada formada revela-se de forma contínua e uniforme. A morfologia analisada está apresentada na micrografia da Figura 5a, e nela os microcristais estão menos poliédricos e mais arredondados (Figura 5b). Os picos do espectro EDS indicam a presença também de Cr, Fe, Mn, O (Figura 5d). 


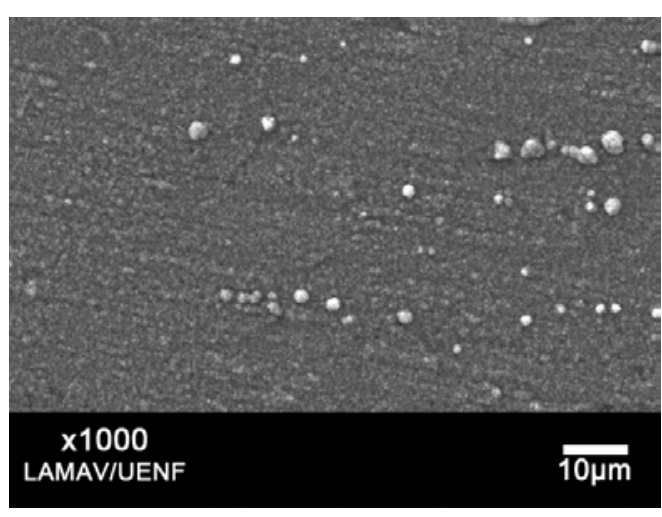

(a)

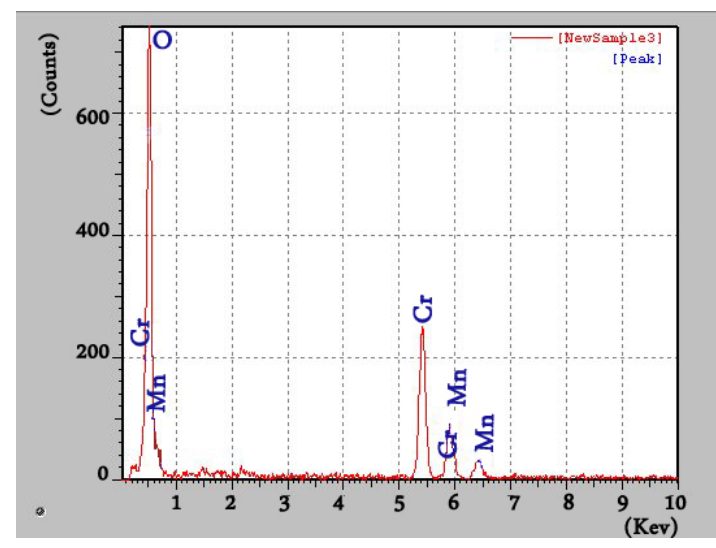

(c)

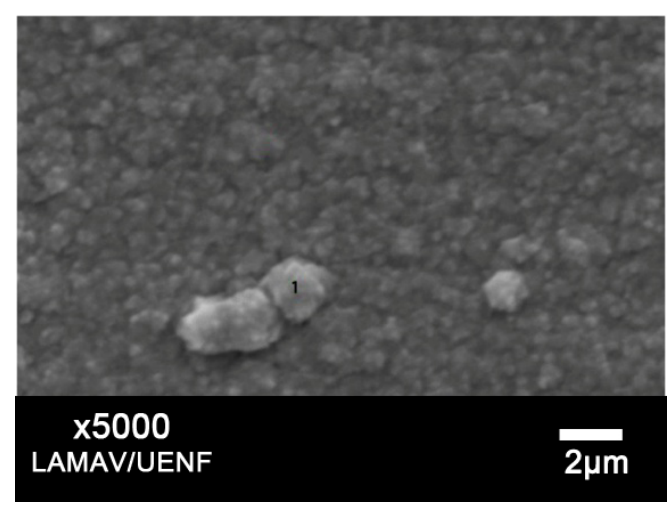

(b)

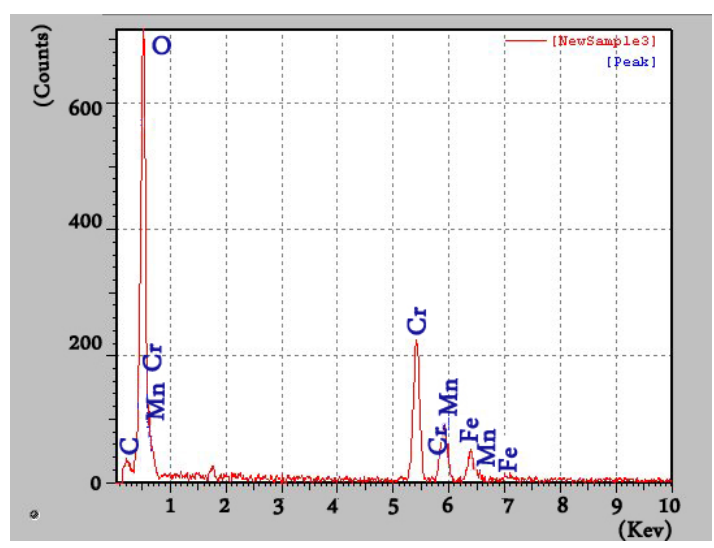

(d)

Figura 5: Material tratado a $850^{\circ} \mathrm{C}$ por 12 horas (a) camada de óxidos; (b) microcristais; (c) espectro EDS da partícula do ponto 1; (d) espectro EDS do ponto 2.

\subsection{Material tratado a $1050^{\circ} \mathrm{C}$}

A camada de óxidos do material tratado a $1050^{\circ} \mathrm{C}$ durante 3 horas apresenta a morfologia mostrada na Figura 6a. Primeiramente, pode ser visto que a espessura da camada aumentou com o tratamento térmico nesta temperatura, apesar do pouco tempo de tratamento. Na Figura 6b, pode-se ver que esta camada é contínua e está constituída por agrupamentos dos microcristais formando uma espécie de “nódulos” de maior espessura, limitados por “contornos” que na verdade são regiões da camada com menor espessura. As observações com maiores aumentos (Figura 6c) mostram que os microcristais são poliédricos e a análise EDS (Figura 6d) nestes cristais indicam que são óxidos de $\mathrm{Cr}$, Fe, e Mn.

Com tratamento térmico durante 10 horas a $1050^{\circ} \mathrm{C}$, a camada de óxidos atinge maior espessura e os “nódulos” e microcristais também são maiores (Figura 7a-b). A composição química e a morfologia poliédrica continuam iguais (Figura 7d). Também é importante mencionar que em amostras tratadas neste tempo e temperatura foi retirada a camada de óxidos e realizada a observação da microestrutura do material. Observou-se que nesta temperatura ocorreu um mecanismo de crescimento dos grãos do material em comparação com o material como recebido (Figura 1); e este fato pode ser verificado na micrografia da Figura 8, o tamanho médio de grão encontrado nesta condição foi de $60 \mu \mathrm{m}$. 


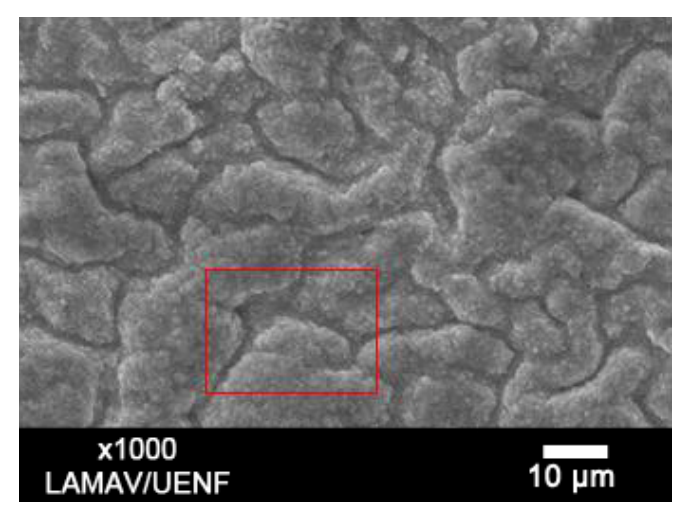

(a)

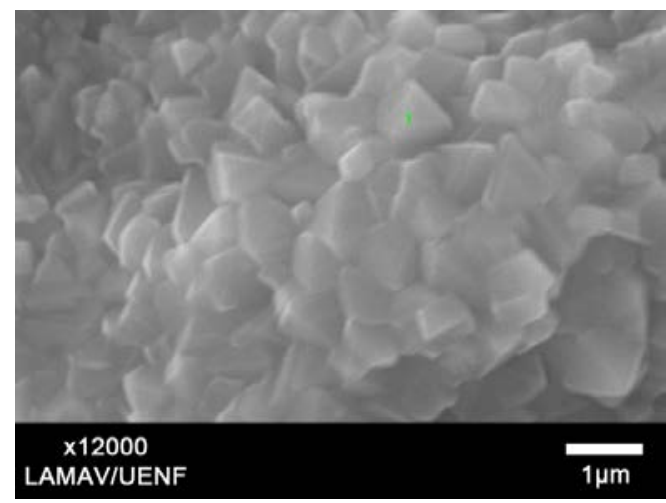

(c)

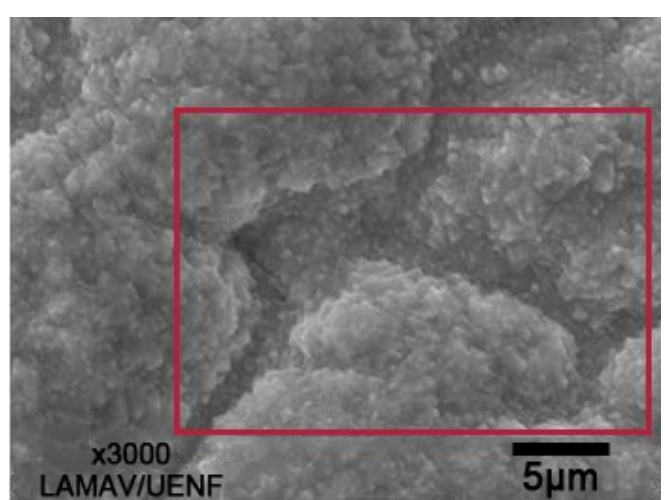

(b)

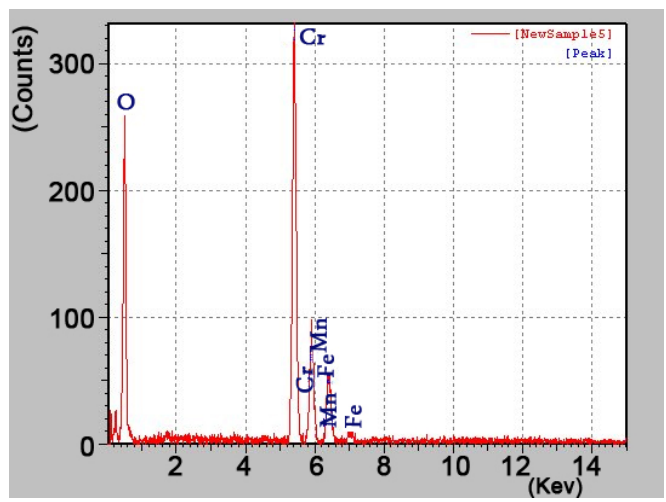

(d)

Figura 6: (a) Micrografia da camada oxidada do material tratado a $1050^{\circ} \mathrm{C}$; (b) "nódulos" e "contornos das regiões de maior e menor espessura; (c) agrupamento de microcristais. (d) espectro EDS sobre os microcristais. 


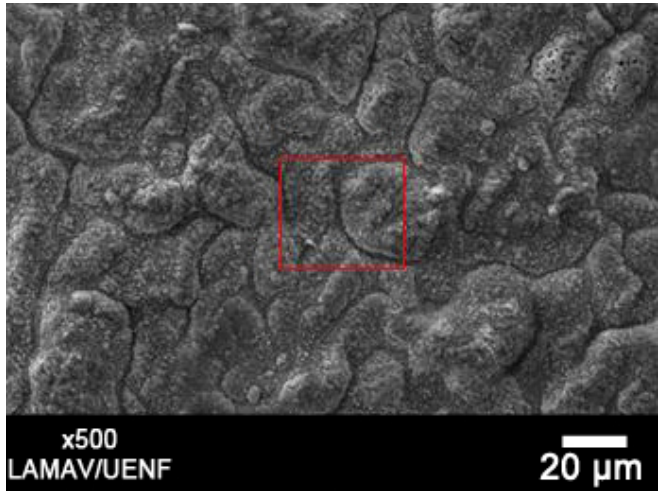

(a)

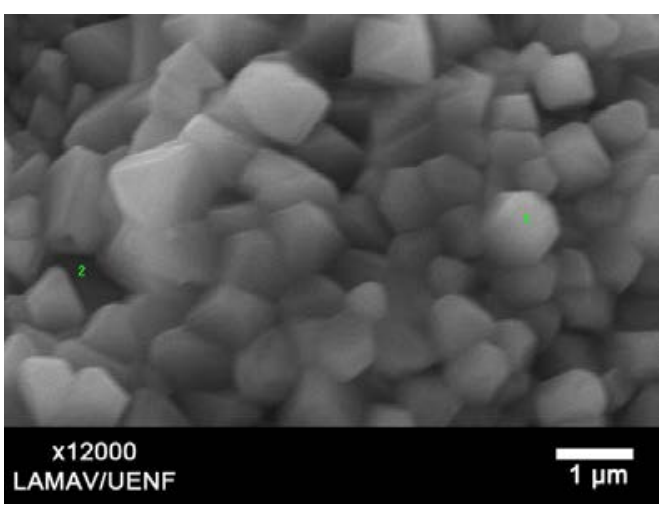

(c)

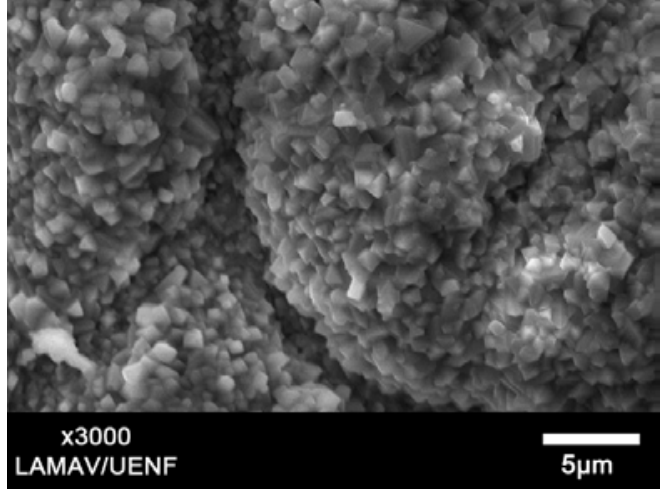

(b)

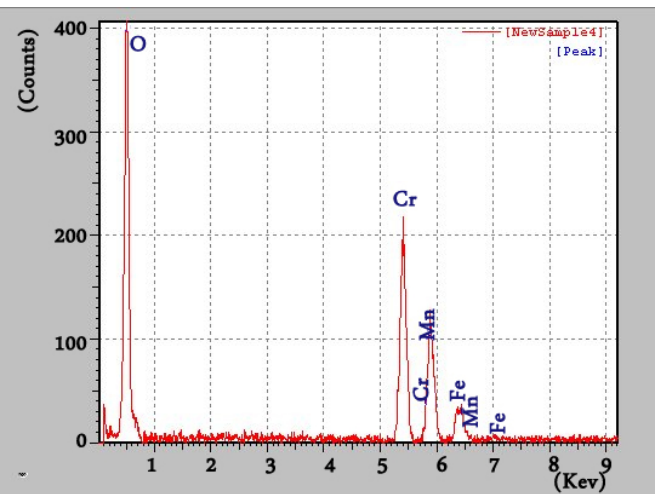

(d)

Figura 7: Material tratado a $1050^{\circ} \mathrm{C}$ por 10 horas: (a) “nódulos” de monocristais; (b) “contorno” entre os "nódulos”; (c) microcristais poliédricos; (d) microanálise EDS dos micorcristais.

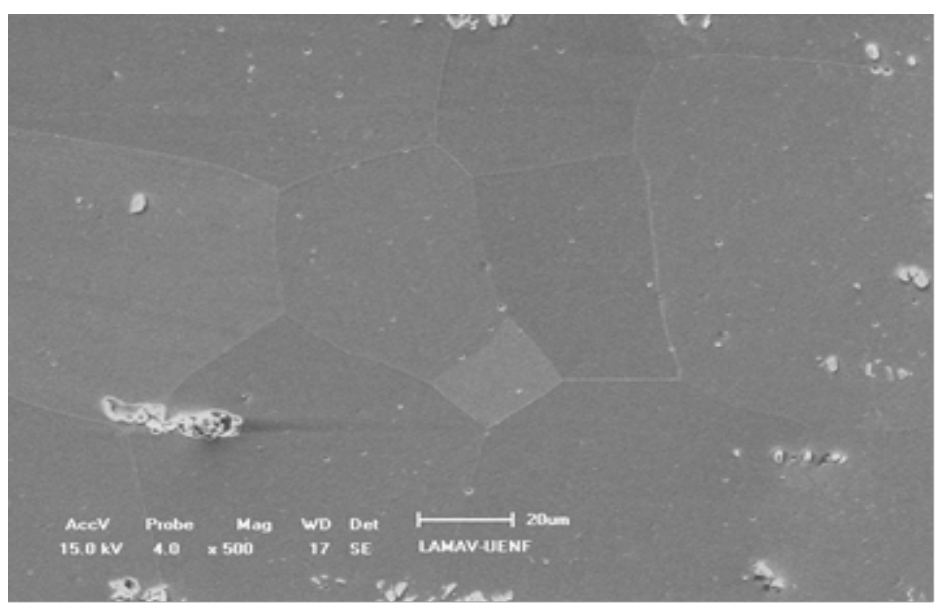

Figura 8: Microestrutura resultante do material tratado a $1050^{\circ} \mathrm{C}$ por 3 horas.

\subsection{Difração de raios $X$}

Com o objetivo de complementar as análises e as observações no MEV sobre a análise microestrutural do material e a composição química e estrutural da camada oxidada, foram realizadas análises de raios-x das amostras. A Figura 9.a mostra o difratograma do material na condição como recebido, e os picos principais com maior intensidade foram identificados como sendo dos planos: (211), (200) e (110) da ferrita (Fe-Cr), o 
que confirma que é a fase principal no material nesta condição.

Com o tratamento a altas temperaturas, por exemplo, a $1050^{\circ} \mathrm{C}$ por 10 horas, tem-se a formação de uma camada de óxido espessa. Nesta condição, o difratograma do material apresentado na Figura 9.b mostra os picos de ferrita (Fe-Cr) com menor intensidade e os picos referentes aos vários óxidos dos elementos que constituem a camada que se apresentam bem definidos. Os resultados aqui adquiridos estão em concordância com os obtidos por outros autores em temperaturas e tempos dentro do intervalo realizado neste trabalho $[6,12,13,14]$.

Duas considerações importantes devem ser levadas em conta para utilização deste tipo de aço inoxidável como interconector de PaCOS devido à sua degradação nestes níveis de temperaturas: 1) a composição química da camada de óxidos formada é constituída principalmente por $\mathrm{Fe}, \mathrm{Mn}$ e $\mathrm{Cr}$, que pode interferir no processo de deposição do filme (que normalmente é a cromita de lantânio) prejudicando a sua aderência; 2) a espessura desta camada pode influenciar nas propriedades ou função do interconector na face ou lado que não está coberto e em contato com o ar durante a operação das pilhas.
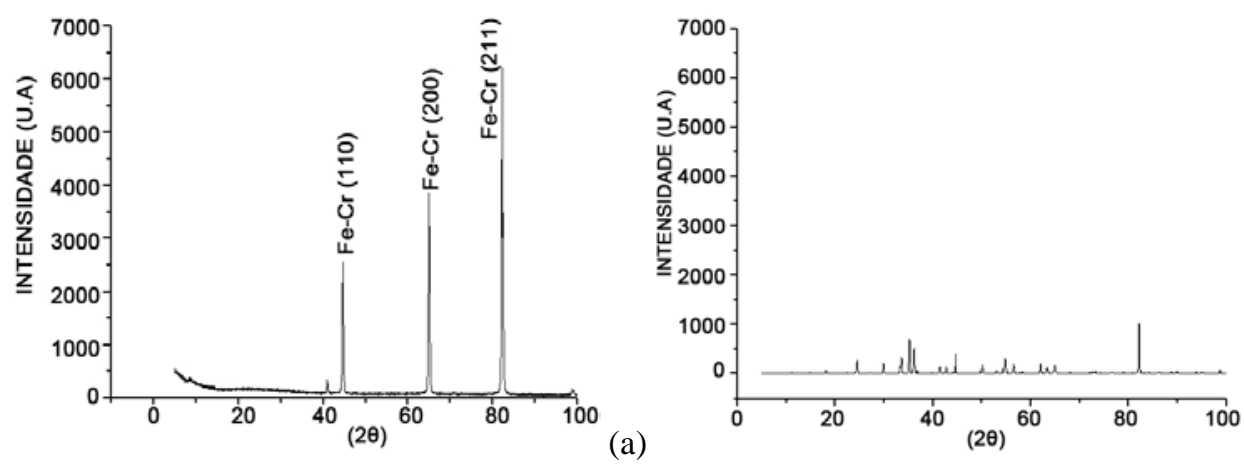

Figura 9: (a) Difratograma material como recebido; (b) difratograma do material tratado a $1050^{\circ} \mathrm{C}$ por $10 \mathrm{~h}$ com presença da camada oxidada.

\section{CONCLUSÕES}

A partir deste estudo sobre influência da temperatura na microestrutura e na oxidação de um aço inoxidável ferrítico 430 visando a sua utilização como interconector para PaCOs pode-se concluir o seguinte:

1. O material na condição como recebido apresenta uma microestrutura monofásica de grãos equiaxiais da fase ferrita (Fe-Cr) praticamente livre de partículas de segunda fase;

2. Quando tratado na temperatura de $650^{\circ} \mathrm{C}$ por 3 horas, aparecem pequenas partículas no material caracterizadas como carbetos. Observou-se evidência da formação de uma camada de óxido muito fina na superfície a qual não interferiu na observação da microestrutura;

3. No tratamento do material a $850^{\circ} \mathrm{C}$ por 3 horas observou-se a formação de uma camada de óxido, consistindo de nódulos os quais por sua vez são constituídos de pequenos microcristais. Quando o tempo foi aumentado para 12 horas, verificou-se que a camada de óxido formada é mais espessa e ainda se mantem contínua;

4. Com o tratamento de $1050^{\circ} \mathrm{C}$, a microestrutura resultante teve variação em comparação ao material como recebido constituindo de grãos maiores, produto do mecanismo de crescimento anormal. Nesta temperatura houve um aumento na quantidade de microcristais tornando a camada oxidada formada bastante espessa e contínua;

5. A análise EDS e a difração de raios-X mostram a presença de Cr, O, Fe e Mn como constituintes da camada oxidada na forma dos óxidos que podem influenciar na deposição do filme e durante a operação da pilha.

\section{AGRADECIMENTOS}

Os autores agradecem à UENF, à Rede PaCOS e ao Laboratório de Filmes Finos do LAMAV- UENF pelo apoio para esta pesquisa. 


\section{BIBLIOGRAFIA}

[1] HWANG, H.J, LEE, E.A, LEE, S., et al., "Sol-gel derived $\left(\mathrm{La}_{0.8} \mathrm{M}_{0.2}\right) \mathrm{CrO}_{3}(\mathrm{M}=\mathrm{Ca}$, Sr) coating layer on stainless-steel substrate for use as a separator in intermediate-temperature solid oxide fuel cell”, Journal of Power Sources, v. 157, pp. 709-713, 2006.

[2] GAZDA, M., JASINSKI P., KUSZ, B., et al., "Evaluation of porous 430L stainless steel for SOFC operation at intermediate temperatures”, Journal of Power Sources, v. 181, pp. 31-37, 2008.

[3] GUTH, U., SHUK, P., TICHONOVA, L., "Materials for electrodes bases on rare-earth manganites", Solid State Ionics, v. 68, n. 3-4, pp. 177-184, 1994.

[4] IVERS-TIFFÉE, E, WEBER, A., "Materials and concepts for solid oxide fuel cells (SOFCs) in stationary and móbile applications”, Journal of Power Source, v. 127, pp. 273-283, 2004.

[5] CHEN, W., IVEY, D., SHAIGAN, N., "Co/LaCrO ${ }_{3}$ composite coatings for AISI 430 stainless steel solid oxide fuel cell interconnects”, Journal of Power Sources, v. 185, pp. 331-337, 2008

[6] CHEN, H., GANNON, P., RUFNER, J., et al., "Oxidation behavior of stainless steel 430 and 441 at $800^{\circ} \mathrm{C}$ in single (air/air) and dual atmosphere (air/hydrogen) exposures”, International Journal of Hydrogen Energy, v. 33, pp. 1392-1398, 2008.

[7] GEMMEN, R., JOHNSON, C., ORLOVSKAYA, N., "Nano-structured self-assembled LaCrO3 thin film deposited by RF magnetron sputtering on a stainless steel interconnect material”, Composites, Part B: Engineering, v. 35, n. 2, pp. 167-172, 2004.

[8] MABUCHI, M., NAKANISH, M., SAITO, N., et al., "Application of equal channel angular extrusion on strengthening of ferritic stainless steel”, Journal of Materials Science, v.36, pp. 3229-3232, 2001.

[9] ABREU, H.F.G., BRUNO, A.D.S., CARVALHO, S.S., et al., "Effect of high temperature annealing on texture and microstructure on an AISI 444 ferritic stainless steel”, Materials Characterization, v. 57, pp. 342347, 2006.

[10] DAÍ, S., LIU, X., HAN, H., et al., "Structure change of 430 stainless steel in the heating process", Journal of University of Science and Technology Beijing, v. 15, n. 1, pp. 34, 2008

[11] ABREU, H.F.G., HERCULANO, L.F.G., SOUZA, C.M., et al., "Microstructural, magnetic and mechanical property changes is an AISI 444 stainless steel aged in the $560^{\circ} \mathrm{C}$ to $800^{\circ} \mathrm{C}$ range", Materials Characterization, v. 59, pp. 112-116, 2008.

[12] DE SOUZA, C.R.C., Caracterização termo-mecânico de Interconectores metálicos depositados com $\mathrm{LaCrO}_{3}$, Dissertação de M.Sc., UFRN, Natal, RN, Brasil, 2010.

[13] FURUICHI, R., ITOHD, M., KONNO, H., et al., "The effect of the oxidation atmosphere on the initial oxidation of type 430 stainless steel at 1273K", Corrosion Science, v. 40, n. 2/3, pp. 191-200, 1998.

[14] DENG, X., PETRIC, A., REZA BATENI, M., et al., "Spinel coatings for UNS 430 stainless steel interconnects”, Surface and Coatings Technology, v. 201, n. 8, pp. 4677-4684, 2007. 